\title{
Level Of Customization Of Twenty American Companies To Spain
}

Teresa Lazcano Bello, Saint Louis University, USA

\begin{abstract}
The aim of this study is to demonstrate if American companies are culturally customizing their websites to the Spanish market and how effectively they are doing it. There are five levels of web customization: standardized, semi-localized, localized, highly-localized, and culturally customized websites (Singh and Pereira, 2005.) How do 20 American companies customize their websites for the Spanish market? The findings of this study is the starting point from many companies that actually operate in the Spanish market.
\end{abstract}

\section{INTRODUCTION}

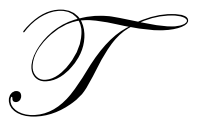

he total number of worldwide internet users is 1.17 billion according to InternetWorldStats.com, and this number is increasing each year (2007). Not only the number of worldwide internet users has increased in the past decade, but also has the online Spanish-speaking market been growing. Organizations like Nielsen net ratings and Nua Internet surveys estimate the online Spanish-speaking population today is approximately 50 million people. This is about $20 \%$ of the total internet users in the world.

Evolution of e-commerce is breaking the mold of how e-commerce sites are created, maintained and driven. E-commerce can be defined as "the online transaction of business, featuring linked computer systems of the vendor, host, and buyer. Electronic transactions involve the transfer of ownership or rights to use a good or service" (Export.gov). Most people are familiar with business-to-consumer electronic business (B2C). Some examples are: Amazon.com, llbean.com, CompUSA.com, travelocity.com, and hotels.com. In Europe, the European Commission has taken a strong position on the e-strategy of companies with a financing of $100 \mathrm{M}$ euros to encourage the development of the use of the Internet, create a multicultural environment, and encourage the creation of contents (Tixier, 2005).

In Spain, according to the Asociación Española de Comercio Electrónico (AECE), e-commerce between businesses (B2B) generated 30,500 millions of euros in the last year (2007). This is an increment of 8\% compared to 2006. Taking this into account, e-commerce has increased substantially in Spain and there is still room for more growth. According to the CIA Factbook, Spain is a country with almost 41 million people (2007). Sometimes international companies fail to customize their websites to Spanish because they tend to think that since the spoken language is Spanish, it would be the same for Latin American countries (Luna et al, 2002). In fact, Spain is culturally and geographically a different country than those in Latin and South America and companies should take that into account when they customize their websites. Spain has a large and advanced telecom market. Internet use and broadband penetration are both below the EU average, but solid competition and considerable investment in broadband infrastructure has enabled the country to catch up quickly (Internet World Stats, 2007). Thus, the Spanish market user is increasing with solid competition. Companies should differentiate themselves by customizing their websites to reach the larger number of potential consumers.

The importance of culturally customizing a website to a target market - in this case Spain - is critical to attract new consumers, obtain a more favorable attitude toward the site (Wu, 1999, Luna et al, 2002), increase purchase intentions (Pereira, 1998), and for better accessibility, usability and interactivity (Dholakia et al, 1998, Luna et al., 2002; Simon, 2001; Tsikriktsis, 2002, Yeo el at. 1998). The aim of this study is to demonstrate if American companies are culturally customizing their websites to the Spanish market and how effectively they are doing it. There are five levels of web customization: standardized, semi-localized, localized, highly-localized, and 
culturally customized websites (Singh and Pereira, 2005). How do 20 American companies customize their websites for the Spanish market? (See Appendix A)

\section{LITERATURE REVIEW}

Past studies are also taken into account in this research paper. There are many studies about consumer preferences on the website and the characteristics of Spanish consumers.

According to CNET Networks, the more culturally customized the website, the higher the response of potential consumers. "Fifty to $75 \%$ of consumers do not complete online purchases of items they want because of poorly designed websites. The most frequent button clicked on e-retail sites is the back button, which is an expression of people's frustration with poor site design and frustration with e-shopping experiences. If e-retailers are to succeed, they are going to have to create trust and exceed customers' expectations better than they have in the past" (CNET Networks, 2001). Once again, it is important that companies customize their websites for a better attitude of the consumer.

Singh, et al. presented the idea of the importance of website adaptation to the culture that it is targeted to (Singh et al, 2007). The importance of this is that depending of the level of adaptation of the website, the attitude toward the site and the purchase intention also differs. In the case of Spain, if the level of adaptation is low, then the attitude toward the site is 2.82 (in a scale of 1 to 5), whereas if the level of adaptation is high, the attitude toward the site becomes almost double (to 4.31). The same happens to purchase intention increasing from 2.67 in low adaptation to 4.14 if high adaptation is used. The study not only measures that, but it also takes into account that the degree "degree of cultural adaptation on the web affects consumer perception of site effectiveness". To conclude, it is not enough for a company to adapt their website just linguistically, but also to localize other elements that will provide a higher attitude of consumers' purchases.

Riefler studied the consumer animosity toward foreign products and the importance of this topic in international marketing for the websites (Petra, 2007). She states that the willingness of a consumer to buy a foreign product has a lot to do with the design of the web page. If the consumer feels that he is connected to the website, then his/hers willingness to buy is greater than if the website has no adaptability. The study is based on consumer animosity, the reasons why it happens and some solutions about it. Riefler also demonstrates "that animosity targets of consumers cannot be considered as being given, i.e. consumers differ in their animosity targets, and there may be a number of (different) reasons causing these feelings, such as economic, political, religious or personal" (Petra, 2007). To summarize, there are many different aspects that should be taken into account in consumer animosity toward a website, not only the design.

Another study explores how differences in culture affect adaptation of the web content by business to consumer's e-commerce firms (Singh et al, 2004). It also states that to "effectively target and reach consumers on the worldwide web, companies need to determine what level of website adaptation is necessary." When adapting a website, the company should take into account not only the language of the country, but also the adaptation of the cultural elements (Luna et al. 2002). This way the content of the website is congruent with the culture that is being targeted to.

Past researches of electronic commerce have provided some preliminary steps to develop a basic electronic commerce website (Ballenger, 2007, Luna et al, 2002, ). The website features will be easy to navigate, take users accessibility into account, use graphic images as appropriate, be easy to read, be visually appealing, encourage visitors to explore the site, entice visitors to purchase, and employ a consistent visual theme.

Past studies have also shown the importance of adapting the web pages to different foreign internet markets. It seemed there was a certain harmony between these local sites, thanks to the presence of the same logo, color, and typography for the agency's name. The rest (design, shape, and architecture) was quite variable (Tixier, 2005). Most of the time, it is not enough to adapt or customize your website by adapting the language. There are other aspects just as important as language that should be taken into consideration, such as icons, numbers, pictures, 
colors, etc. The purpose of this paper is to show how American companies have adapted their website towards the Spanish market and how effectively they have done it.

\section{METHODOLOGY}

This study is mainly based on a previous study that focused on the level of culturally customized websites and the different features that a company must accomplish to be effective in the target market that they are trying to reach. This study is based on the book "The Culturally Customized Web Site" (Singh and Pereira, 2005).

Singh and Pereira developed a model to culturally customize a website based on a five-step process (2005). The first step is to identify the target country, which in this case is Spain. The second step is to locate the target country in Culture map 1 (Singh and Pereira, 2005). Spain is identified as a country with strong uncertainty avoidance and femininity. The web features associated with this are the use of customer service, guided navigation, traditional theme, local store, local terminology, free trials/downloads, toll free numbers, transaction security, soft sell approach, and the use of aesthetics. The third step is to locate the target country in Culture map 2 (Singh and Pereira, 2005). Spain is located in the fourth quadrant with large power distance and individualism. The fourth step is to identify the web features associated with power distance and individualism. These features are: firm hierarchy info, images of management, quality assurance, vision statement, pride of ownership, relevant titles, privacy statement, independent theme, product uniqueness, and personalization. The success of a culturally customized website is based on these five steps. If they are followed, then the website will become culturally congruent (Luna et al, 2002) to Spanish culture and society.

The type of website customization varies from company to company. As presented above, there are five categories of website globalization (Singh and Pereira, 2005). Table 1 shows the category in which each company is performing in Spain.

The first level is the standardized website, characterized by a single website for the entire global market (Singh and Pereira, 2005). In this study, the websites from the companies selected satisfy this category. Of the 20 companies, not a single one is in this basic category.

The second category is the semi-localized website. There is still one website for the global market, but contact information about foreign subsidiaries is available for international customers (Singh and Pereira, 2005, Luna, 2002). An example of this would be Johnson and Johnson; it is the only company that did not provide a website for the Spanish market. Moreover, they have a very strong presence in Spain with many different types of products and brands that are well known. Once again, in this study, we find out that $5 \%$ of the companies are in this category.

The third category is the localized website, characterized by providing country specific websites (Singh and Pereira, 2005). In the study, $60 \%$ of the companies are in this category. They create a specific web page for Spain; however, most of these websites are not highly localized or culturally customized for many reasons. A good example is General Electric's website for Spain (www.ge.com/es) where the home page and another page are translated, but the rest are still in English. Many other companies failed to translate all of their pages.

The fourth category is the highly localized website, characterized by country specific websites with language translation, including other levels of adaptation in terms of variables, such as time, zip code, numbers, etc. (Singh and Pereira, 2005). During the study, just 35\% of the websites fell into this category. A good example is Apple (www.apple.es) where they adapted their URL to Spain. Other companies that scored high in this category are Kellogg's (www.kelloggs.es) and Intel (www.intel.es). Both companies demonstrate to have superior adaptation by providing different websites with the information culturally congruent with the Spanish culture.

The fifth and last category is the culturally customized website, which includes a complete immersion in the country that is being targeted, Spain in this case. Customizing a website consists of integrating an entire site in the language and culture of a country and it means making a site completely adequate for the final user (Singh and Pereira, 2005; Tixier, 2005). Twenty companies were analyzed in this study and, in fact, none of them fit into this 
category as they did not reflect a level of cultural adaptation in perception, symbolism and behavior (Singh and Pereira, 2005).

There are two components that can be addressed to this study. The first one is to identify the category in which each company is right now, and the second one is to evaluate the different web features that are present in each website. The method used for the second component is to analyze each website and see how the different companies accomplish the various web features.

\section{RESULTS}

The aim of this study is to demonstrate the different levels of categories of 20 American companies when creating a website for Spain (See Appendix A). The different web features presented above are directly influenced by the cultural values of individualism/collectivism, high/low power distance, high/low uncertainty avoidance, and masculinity/femininity (Hofstede, 1997). According to the five-step process, Spain is characterized as high power distance, individualistic, and feminine, and consists of highly uncertainty avoidance dimensions (Singh and Pereira, 2005).

\section{High Power Distance}

The features that would help a website address the high power distance for Spain are: the use of hierarchy information, the use of images of management people, quality assurance and awards, the use of vision statement, and pride of ownership appeal. The United States is a country that assumes to have a low power distance, meaning that society believes that powers should be equally distributed (Hofstede, 1997; Singh et al, 2005). Many of the American companies used in this study did provide, in their English version, most of these features; however, they were not added as a part of their Spanish website, thus they were not properly translated. (See Table $\mathbf{2}$ for details)

The use of hierarchy information is very important because countries with high power distance are those that accept power and hierarchy in their society. From all the companies used in this study, just $10 \%$ provided a proper link to their corporate team; however, about 55\% of the companies provided a link to their English version. These two companies are Microsoft (www.microsoft.com/es/es/default.aspx) and Accenture (www.accenture.es), providing not only hierarchy information about the company, but also images of their team members. It is necessary that companies understand the importance of providing this type of information to countries with high power distance, such as Spain. The other 55\% of the companies that provided the information, but in English, assumed that Spanish people would know English; so companies should provide the information in the language in order to be congruent with society.

Another feature is quality assurance and awards. Award, certifications, and recognitions are different ways in which a potential customer will value the product provided (Singh and Pereira, 2005). Just 20\% of the companies provided a place for awards and certificates in their Spanish version of their website. Once again, some of the other companies provided this information in their American website and just added a link to the Spanish website. Accenture (www.accenture.es) not only provided the information in the right language in their website, but they also added a section for the different awards it received in different years. So they have a section for 2008 awards, a section for 2007 awards, etc.

Overall, the companies that best accomplished the high power distance web features are Accenture (www.accenture.es) and Microsoft (www.microsoft.com/es/es/default.aspx $)$ who presented four of the five web features of this type of dimension. The average of all the companies was about $23 \%$, which means that the overall average for these companies was the accomplishment of at least one web feature.

\section{Femininity And Individualism}

Before entering into the cultural value of femininity, it is necessary to clarify that Spain is more feminine/masculine (in between them). The femininity aspect of the websites scored poorly. Just 50\% of the companies took a soft sell approach and $40 \%$ of the companies used aesthetics. Again, these results could be 
because Spain is a fine line between masculine and feminine and some companies do not know how to approach (See Table 3 for details). The overall procedure is $45 \%$ of them use femininity to culturally customize their website.

Spain is considered a individualistic country (See Table 3 for details). The dimension to be identified with individualism versus collectivism was most strongly associated with the relative importance attached to the following goal items: the use of privacy statements, independence theme, product uniqueness, and personalization (Hofstede, 1997; Singh et al, 2005). From the result in Table 3, we can see that the average was 50\% use of individualistic features in the different websites. Kellogg's (http://www.kelloggs.es), Walt Disney (http://www.disney.es), and Nike (http://www.nike.com/g1/eu/index.jhtml?lang=1,3) were the only companies to integrate the four different features for an individualistic country that were present in their websites.

\section{High Uncertainty Avoidance}

Under the five stage process, Spain is considered to be a country with high uncertainty avoidance. Table 4 shows the different features that companies need to include to their websites in order to be culturally adapted. This means that Spanish people tend to avoid ambiguous situations and that they like to feel secure on the website. The different features that characterized a high uncertainty avoidance value are: customer service, guided navigation, traditional theme, local stores, local terminology, free trials, toll free number, and transaction security (Singh et al, 2005). Uncertainty avoidance is the reduction of ambiguity (Hofstede, 1997).

Customer service refers to a link visible on the home page and a Blog that will help customers learn more about the company, as well as FAQs and a customer service e-mail. Customer service is an essential key for countries with high uncertainty avoidance, and just $80 \%$ of the companies provide this feature in their Spanish website. Another feature in which the companies scored rather high (about 85\%) was guided navigation. This includes site maps, well-displayed links, etc. About $85 \%$ of the companies included a site map that was easy to find in their website. About $15 \%$ did not have a site map, thus the navigation was harder to use. None of the web pages included directions or instructions for the use of the different web pages. In general, the feature with the lower score was Free Trials, and just two companies incorporated this into their Spanish websites (which means that 10\% of the companies used it). Kellogg's (www.kelloggs.es) and Coca-Cola (www.cocacola.es) had free trial products that consumers could try and purchase later on. However, later on the free trials are harder to find or obtain because even if you ask for them online, sometimes the customers do not receive them. The feature least present among the websites is free trials; just 55\% of the companies used this in their Spanish websites. An example is IBM (http://www.ibm.com/es) who provided promotions and free trials for some of the computers, such as Lenovo 3+. This promotion includes a three-month free trial of the computer.

The average usage of features in the websites is $59 \%$. This means that of the eight different features, only about five of the eight are present in most of the companies' websites. Overall, the companies that perform better by including the high uncertainty avoidance features in their website are those that scored a $87.5 \%$ (meaning that they presented seven of the eight features recommended). These companies are Citigroup, General Electric, Kellogg's, HP, and Apple.

\section{IMPLICATIONS}

The main implication of this study is to reflect the importance of companies to adapt their web pages to their different target markets by analyzing 20 American companies and their level of customization. For nearly all companies, an Internet presence is no longer an issue, but rather a question of how the website can be used to add value to the company's business. Even domestic companies have to take this into consideration (Junglas and Watson, 2004; Cook et al, 2005). In this study, we used 20 American companies operating in Spain that sell a product or a service and have a factory. It is important to realize that these 20 American companies are operating in Spain; however, their level of adaptation of their website is not the best they can do.

According to the National Statistics Institute (Instituto Nacional de Estadística--INE), 60.4\% of Spanish households with at least one person aged 16-74 had a computer in 2007, an increase of 3.2 percentage points from a 
year earlier, while 39\% of Spanish homes had a high-speed Internet connection, 10 percentage points more than in 2006 (EIU ViewsWire, 2008).

Geert Hofstede defined five cultural dimensions: power distance, collectivism/individualism, femininity/masculinity, uncertainty avoidance, and long/short-term orientations (Hofstede, 1997; Singh et al, 2005). We analyzed the different features from each cultural value and we realize that American companies are adapting their web pages to Spain in different ways. The web is a young and rapidly evolving medium for commercial activity. Undeniably, culture should be accounted for when designing websites (Cook and Finlayson, 2005). In fact, what applies to one company in a certain sector of one country does not necessarily apply to a comparable company in the same sector in another country. National characteristics and culture play a key role in determining human interaction of all forms, including electronic communication (Junglas and Watson, 2004).

Thus, the aim of this study is to inform of the importance of culturally customizing a website to a particular market in congruency with the culture. The purpose of this paper was to analyze a number of American companies that are considering becoming global companies and to see the effectiveness of their customization. The average level of customization was under the category of Localized Website, which is about $60 \%$ of the companies, meaning that companies' websites offer country specific web pages with translation wherever relevant (Singh et al, 2005). Simply translating content is not enough. An example is a U.S. airline that advertised its new leather first-class seats to the Mexican market. It simply translated its "fly in leather" slogan to Spanish and it came out as "fly naked." The language must be culturally attuned (Middlemiss, 2001).

What can companies do to improve the adaptation of their websites? According to the five-step process, Spain is characterized as high power distance, individualistic, feminine, and with high uncertainty avoidance dimensions (Singh and Pereira, 2005). The 20 companies' average score on the high power distance feature was 23\% (See Table 2). In fact, the features that lacked most were firm hierarchy info and the images of the management, with just $2 \%$ of the companies using them in their Spanish websites. It is true that most of the companies in this study provided the information, but not in the right language. Most of the companies provided the company information by adding a link on their Spanish website to their American website. The Spanish market is not able to access this information mainly due to language barriers. Consequently, web users from Spain prefer website characteristics that meet their distinct needs, femininity, individualism, high uncertainty avoidance, and high power distance (Singh et al, 2005, Luna et al., 2002; Simon, 2001; Tsikriktsis, 2002). We believe that if the companies improve on a couple of features on their Spanish websites, consumers' reaction to the site will vary substantially to a better attitude of the website (Goldsmith and Lafferty, 2002; Wu, 1999) by increasing the purchase intention of the product or service (Pereira, 1998).

These findings have important implications for researchers and managers of multinational companies operating abroad: 1) No prior study supports the finding of content used in this experimental study, 2) Its purpose was to demonstrate the level in which American companies are adapting their websites to the Spanish market with specific examples of it, and 3) Few studies have investigated the existence of cultural dimensions in websites (Zahedi et al., 2006).

\section{CONCLUSION}

This study extends previous works on culturally customizing websites to the Spanish market by using the approach of Hofstede (1997), later on studied by Singh et al. (2005), and many other individual studies. The results support Singh's et al (2005) argument that companies are not culturally customizing their websites to be congruent with the culture. Instead, the finding suggests that multiple companies operating over the internet in Spain fail to culturally adapt their websites. The online behaviors of consumers are subtly different in nature from traditional consumer behaviors due to the unique characteristics and interplay of technology and culture (Chau et al., 2002).

Most American sites have not yet considered culturally customizing their website. Only 55\% of American companies have made no effort to adapt to the needs of foreign visitors (Tixier, 2005); and in this study, 35\% of the companies were found with highly localized websites and $60 \%$ where found to be just localized. In conclusion, this 
study is the starting point to help American companies realize the importance of this issue and thus, the importance of having a culturally-customized website in Spanish.

\section{APPENDIX A: Twenty American Companies}

1 Citigroup

2 General Electric

3 IBM

$4 \quad$ Procter and Gamble

5 Microsoft

$6 \quad$ Kellogg's

7 Walt Disney

8 Coca-Cola

9 Intel

10 Pepsi

11 Nike

12 Dow Chemical

13 Hewlett- Packard

14 Johnson and Johnson

15 Reebok

16 Motorola

17 Accenture

18 McDonalds

19 Apple

20 Alcoa <http://www.citigroup.com/citi/global/esp.htm>

$\langle$ http://www.ge.com/es/>

$\leq$ http://www.ibm.com/es/>

$\leq$ http://www.pg.com/es_ES/>

$\leq$ http://www.microsoft.com/es/es/default.aspx $>$

$\leq$ http://www.kelloggs.es/>

$\leq$ http://www.disney.es/>

$\langle$ http://www.cocacola.es/>

$\leq$ http://www.intel.com/index.htm\#/es_ES_01>

$\langle$ http://www.pepsi.es $\rangle$

$\langle$ http://www.nike.es $>$

$\langle$ http://www.nike.com/nikeos/p/nike/es_ES/>

〈http://www.hp.es>

$\langle$ http://www.jnj.com>

$\langle$ http://www.reebok.es>

$\langle$ http://www.motorola.es $\rangle$

$\langle$ http://www.accenture.es $\rangle$

$\langle$ http://www.medonals.com>

$\langle$ http://www.apple.es>

〈http://www.alcoa.com/spain/en/home.asp>

Table 1: Types of Web Site Customization of twenty American Companies

制

\begin{tabular}{|c|c|c|c|c|c|c|}
\hline & & $\begin{array}{l}\text { Standardized } \\
\text { Web Sites }\end{array}$ & $\begin{array}{l}\text { Semi- Localized } \\
\text { Web Sites }\end{array}$ & $\begin{array}{l}\text { Localized } \\
\text { Web sites }\end{array}$ & $\begin{array}{l}\text { Highly Localized } \\
\text { Web Sites }\end{array}$ & $\begin{array}{c}\text { Culturally } \\
\text { Customized Web sites }\end{array}$ \\
\hline 1 & Citigroup & & & $\checkmark$ & & \\
\hline 2 & General Electric & & & $\checkmark$ & & \\
\hline 3 & IBM & & & $\checkmark$ & & \\
\hline 4 & Procter and Gamble & & & & $\checkmark$ & \\
\hline 5 & Microsoft & & & $\checkmark$ & & \\
\hline 6 & Kellogg's & & & & $\checkmark$ & \\
\hline 7 & Walt Disney & & & & $\checkmark$ & \\
\hline 8 & Coca-Cola & & & $\checkmark$ & & \\
\hline 9 & Intel & & & & $\checkmark$ & \\
\hline 10 & Pepsi & & & $\checkmark$ & & \\
\hline 11 & Nike & & & $\checkmark$ & & \\
\hline 12 & Dow Chemical & & & $\checkmark$ & & \\
\hline 13 & Hewlett- Packard & & & & $\checkmark$ & \\
\hline 14 & Johnson and Johnson & & $\checkmark$ & & & \\
\hline 15 & Reebok & & & $\checkmark$ & & \\
\hline 16 & Motorola & & & $\checkmark$ & & \\
\hline 17 & Accenture & & & $\checkmark$ & & \\
\hline 18 & McDonalds & & & & $\checkmark$ & \\
\hline 19 & Apple & & & & $\checkmark$ & \\
\hline 20 & Alcoa & & & $\checkmark$ & & \\
\hline & TOTAL & & $1(5 \%)$ & $13(60 \%)$ & $7(35 \%)$ & \\
\hline
\end{tabular}


Table 2: Features for High Power Distance and Analysis of the twenty American companies.

\begin{tabular}{|c|l|c|c|c|c|c|r|}
\hline & Firm \\
\hline
\end{tabular}

Table 3 : Features of Femininity and Individualistic by Analyzing of the twenty companies.

\begin{tabular}{|c|c|c|c|c|c|c|c|c|c|}
\hline & & \multicolumn{2}{|c|}{ Feminity } & \multirow[b]{2}{*}{ Total } & \multicolumn{5}{|c|}{ Individunlism } \\
\hline & & $\begin{array}{l}\text { Soft Sell } \\
\text { Approach }\end{array}$ & $\begin{array}{c}\text { Use } \\
\text { Aesthetics }\end{array}$ & & $\begin{array}{c}\text { Privacy } \\
\text { Statem } \\
\text { ent }\end{array}$ & $\begin{array}{l}\text { Independence } \\
\text { Theme }\end{array}$ & $\begin{array}{c}\text { Product } \\
\text { Uniqueness }\end{array}$ & Personalization & Total \\
\hline 1 & Citigroup & & Yes & $50 \%$ & Yes & Yes & & \begin{tabular}{|l|} 
Yes \\
\end{tabular} & $75 \%$ \\
\hline 2 & General Electric & & & & Yes & & & & $25 \%$ \\
\hline \begin{tabular}{|l}
3 \\
\end{tabular} & IBM & Yes & & $50 \%$ & Yes & & & & $25 \%$ \\
\hline 4 & Procter and Gamble & Yes & & $50 \%$ & Yes & & & & $25 \%$ \\
\hline \begin{tabular}{|l}
5 \\
\end{tabular} & Microsoft & & & & Yes & & & & $25 \%$ \\
\hline 6 & Kellogg's & Yes & Yes & $100 \%$ & Yes & Yes & Yes & Yes & $100 \%$ \\
\hline 7 & Walt Disney & Yes & Yes & $100 \%$ & Yes & Yes & Yes & Yes & $100 \%$ \\
\hline 8 & \begin{tabular}{|l|} 
Coca-Cola \\
\end{tabular} & Yes & & & & Yes & & & $25 \%$ \\
\hline 9 & Intel & & & & Yes & & Yes & & $50 \%$ \\
\hline 10 & Pepsi & & & & & Yes & Yes & & $50 \%$ \\
\hline 11 & Nike & & & & Yes & Yes & Yes & Yes & $100 \%$ \\
\hline 12 & Dow Chemical & & & & Yes & & & & $25 \%$ \\
\hline 13 & Hewlett- Packard & Yes & & $50 \%$ & & Yes & Yes & Yes & $75 \%$ \\
\hline 14 & Johnson and Johnson & & & & Yes & & & & $25 \%$ \\
\hline 15 & Reebok & Yes & Yes & $100 \%$ & Yes & & & & $25 \%$ \\
\hline 16 & Motorola & & & & & & Yes & & $25 \%$ \\
\hline 17 & Accenture & Yes & Yes & $100 \%$ & & Yes & & & $25 \%$ \\
\hline 18 & McDonalds & Yes & Yes & $100 \%$ & & Yes & Yes & & $50 \%$ \\
\hline 19 & Apple & Yes & Yes & $100 \%$ & Yes & Yes & Yes & Yes & $75 \%$ \\
\hline 20 & Alcoa & Yes & Yes & $100 \%$ & Yes & Yes & Yes & & $75 \%$ \\
\hline & Total & $\begin{array}{l}\text { 11 Yes } \\
(55 \%)\end{array}$ & $\begin{array}{l}8 \text { Yes } \\
(40 \%)\end{array}$ & $\begin{array}{r}\text { Ayerg } \\
45 \%\end{array}$ & $\begin{array}{c}14 \text { Yes } \\
(70 \%)\end{array}$ & $\begin{array}{l}10 \text { Yes } \\
(50 \%)\end{array}$ & $\begin{array}{c}10 \text { Yes } \\
(50 \%)\end{array}$ & $\begin{array}{l}7 \text { Yes } \\
(35 \%)\end{array}$ & $\begin{array}{r}\text { Ayerg } \\
\mathbf{5 0 \%}\end{array}$ \\
\hline
\end{tabular}


Table 4: Features for High Uncertainty Avoidance and Analysis of the twenty companies. 田

\begin{tabular}{|c|c|c|c|c|c|c|c|c|c|c|}
\hline & & $\begin{array}{c}\text { Customer } \\
\text { service }\end{array}$ & $\begin{array}{c}\text { Guided } \\
\text { Navigation }\end{array}$ & $\begin{array}{c}\text { Traditional } \\
\text { Theme }\end{array}$ & $\begin{array}{l}\text { Local } \\
\text { Stores }\end{array}$ & $\begin{array}{c}\text { Local } \\
\text { terminology }\end{array}$ & $\begin{array}{l}\text { Free } \\
\text { Trials }\end{array}$ & $\begin{array}{c}\text { Toll } \\
\text { Free \# }\end{array}$ & $\begin{array}{c}\text { Transaction } \\
\text { Security }\end{array}$ & Total \\
\hline 1 & Citigroup & Yes & Yes & Yes & Yes & Yes & & Yes & Yes & $87,5 \%$ \\
\hline 2 & General Electric & Yes & Yes & Yes & & Yes & Yes & Yes & Yes & $87,5 \%$ \\
\hline$\frac{2}{3}$ & IBM & Yes & Yes & & & Yes & Yes & Yes & Yes (TRUSTe) & $75 \%$ \\
\hline 4 & Procter and Gamble & Yes & Yes & Yes & & Yes & & Yes & Yes & $75 \%$ \\
\hline 5 & Microsoft & & Yes & & Yes & & Yes & Yes & Yes & $62,5 \%$ \\
\hline 6 & Kellogg's & Yes & Yes & Yes & Yes & Yes & & Yes & Yes & $87,5 \%$ \\
\hline 7 & Walt Disney & & & & & Yes & & & & $12,5 \%$ \\
\hline 8 & Coca-Cola & Yes (Blog) & Yes & & & & Yes & & & $37,5 \%$ \\
\hline 9 & Intel & Yes (Blog) & Yes & & & Yes & Yes & & $\begin{array}{c}\text { Yes } \\
\text { (BBBQnline) }\end{array}$ & $50 \%$ \\
\hline 10 & Pepsi & & Yes & & & Yes & & & & $25 \%$ \\
\hline 11 & Nike & & Yes & & & & Yes & & & $25 \%$ \\
\hline 12 & Dow Chemical & Yes & & & & & & & & $12,5 \%$ \\
\hline 13 & Hewlett- Packard & Yes & & Yes & Yes & Yes & Yes & Yes & $\begin{array}{c}\text { Yes } \\
\text { (BBBQnline) }\end{array}$ & $87,5 \%$ \\
\hline 14 & Johnson and Johnson & Yes & Yes & & Yes & Yes & Yes & Yes & & $75 \%$ \\
\hline 15 & Reebok & Yes & Yes & & & & & Yes & Yes & $50 \%$ \\
\hline 16 & Motorola & Yes & Yes & & & Yes & & Yes & Yes & $62,5 \%$ \\
\hline 17 & Accenture & Yes (Blog) & Yes & & & Yes & Yes & & & $50 \%$ \\
\hline 18 & McDonalds & Yes & Yes & Yes & Yes & Yes & & & & $62,5 \%$ \\
\hline 19 & Apple & Yes & Yes & & Yes & Yes & Yes & Yes & Yes (TRUSTe) & $87,5 \%$ \\
\hline 20 & Alcoa & Yes & Yes & Yes & Yes & Yes & & & Yes & $75 \%$ \\
\hline & Total & $\begin{array}{l}16 \text { Yes } \\
(80 \%)\end{array}$ & $\begin{array}{l}17 \text { Yes } \\
(85 \%)\end{array}$ & $\begin{array}{l}7 \text { Yes } \\
(35 \%)\end{array}$ & $\begin{array}{l}8 \text { Yes } \\
(40 \%)\end{array}$ & $\begin{array}{l}12 \text { Yes } \\
(60 \%)\end{array}$ & $\begin{array}{l}11 \text { Yes } \\
(55 \%)\end{array}$ & $\begin{array}{l}11 \text { Yes } \\
(55 \%)\end{array}$ & $\begin{array}{l}11 \text { Yes } \\
(55 \%)\end{array}$ & $\begin{array}{l}\text { Averag } \\
\mathbf{5 9} \%\end{array}$ \\
\hline & & $\begin{array}{l}3 \text { Blog } \\
(15 \%)\end{array}$ & & & & & & & & \\
\hline
\end{tabular}

\section{REFERENCES}

1. Asociación Española de Comercio Electrónico. Retrieved March 2, 2008: http://www.aece.es/

2. Ballenger, R. (2007). "An eCommerce Development Case: Your Company's eCommerce Web Site.” Journal of Information Systems Education, 18(4), 409-414. Retrieved April 27, 2008, from ABI/INFORM Global database.

3. CIA World Factbook. (March 30, 2008): https://www.cia.gov/library/publications/the-worldfactbook/geos/sp.html\#People

4. $\quad$ CNET Networks. (May 2001). "What Do E-Consumers Want? The Electronic Shoppers." Retrieved March 25, 2008: http://findarticles.com/p/articles/mi_m1272/is_2672_129/ai_74572229

5. Chau, P., Cole, M., Massey, A., and Montoya-Weiss, M., et al. (2002). Association for Computing Machinery. Communications of the ACM. New York: Oct Vol. 45, Iss. 10; p. 138

6. Cook, J., and Finlayson, M.. (2005). "The Impact of Cultural Diversity on Web Site Design.” S.A.M. Advanced Management Journal, 70(3), 15-23,45. Retrieved April 30, 2008, from ABI/INFORM Global database.

7. Dholakia, M., and Rego, L. (1998) "What Makes Commercial Web Pages Popular?" European Journal of Marketing, Vol 32, pages 724.

8. $\quad$ Export.gov. "What is E-Commerce?" March 25, 2008:http://www.export.gov/sellingonline /whatisecommerce.asp

9. $\quad$ Hofstede, G. (1997) "Cultures and Organizations.” New York: McGraw-Hill.

10. Internet World Stats.(2007) "Spain: Internet Usage Stats and Telecom Reports." March 25, 2008: http://www.internetworldstats.com/eu/es.htm

11. Junglas, I., and Watson, R. (2004). "National Culture and Electronic Commerce." E - Service Journal, 3(2), 3-34. Retrieved April 30, 2008, from ABI/INFORM Global database.

12. Middlemiss, J. (March 2001). "Web sites must cater to global audiences." Wall Street \& Technology: ebusiness,24. Retrieved April 30, 2008, from ABI/INFORM Global database.

13. Luna, D., Peracchio, L. A. and de Juan, M.D. (2002), "Cross-cultural and cognitive aspects of web site navigation", Journal of the Academy of Marketing Science, Vol. 30 No. 4, pp. 397-410.

14. Nielsen Net Ratings: http://www.nielsen-netratings.com/ 
15. Nuasoft Website Services. Retrieved March 3, 2008: http://www.nua.ie/surveys/

16. Pereira, R.E. (1998). "Cross-Cultural Influences on Global Electronic Commerce," Proceedings of the AIS, Baltimore, pp. 318-320.

17. Riefler, P. And Diamantopoulos, A.. (2007). "Consumer Animosity: a Literature Review and a Reconsideration of its Measurement.” International Marketing Review, 24(1), 87-Retrieved April 27, 2008, from ABI/INFORM Global database.

18. Simon, SJ. (2001), "The impact of culture and gender on web sites: an empirical study", Database for Advances in Information Systems, Vol. 32 No. 1, pp. 18-37.

19. Singh, N., Kumar, V., and Baack, D. (2005). "Adaptation of cultural content: evidence from B2C ecommerce firms." European Journal of Marketing, 39(1/2), 71-86. Retrieved April 15, 2008, from ABI/INFORM Global database.

20. Singh, N., Furrer, O., and Ostinelli, M.. (2004). "To Localize or to Standardize on The Web: Empirical Evidence from Italy, India, Netherlands, Spain, and Switzerland." Multinational Business

Review, 12(1), 69-87. Retrieved March 27, 2008, from ABI/INFORM Global database.

21. Singh, N. and Pereira, A. (2005). "The culturally Customized Web Site." ElSevier.

22. Singh, N. and Pereira, A. (2005). "Spain economy: E-commerce on the Rise: [1]." (2008, March). EIU ViewsWire. Retrieved April 30, 2008, from ABI/INFORM Global database.

23. Tixier, M. (2005). "Globalization and Localization of Contents: Evolution of Major Internet Sites Across Sectors of Industry" Thunderbird International Business Review, Vol. 47(1) 15-48 •

24. Tsikriktsis, N. (2002), "Does culture influence website quality expectations? An empirical Study", Journal of Service Research, Vol. 5 No. 2, pp. 101-12.

25. Trusted Translations. (2007).” The Online Spanish - Speaking market.” March 25, 2008: http://www.trustedtranslations.com/online_spanish_market.asp

26. Wu, Guohua. (1999) "Perceived Interactivity and Attitude toward Website." Retrieved March 25, 2008: http://www.ciadvertising.org/studies/reports/info_process/perceived_interac tivity.pdf

27. Xavier, D. and Fred, Z. (1997) "Testing Web site design and promotional content." Journal of Advertisement Research 37: 77-91.

28. Yeo, A., Barbour, R., and Apperley, M. (1998). "Cultural Influence In Usability Assessment," in Hanson (ed.), Contemporary Ergonomics, Edinburgh: Institute of Occupational Medicine, pp. 274-278.

29. Zahedi, F., Pelt, W., and Srite, M. (2006) "Web Documents: Cultural Masculinity and Femininity." Journal of Management Information Systems. Vol. 23 Issue 1, p87-128 